\title{
Expression of a colorectal antigen defined by a new monoclonal antibody, CO-TL1
}

\author{
Gerdy B ten Dam ${ }^{1}$, Lambert G Poels ${ }^{2}$, Rogier Pullens ${ }^{2}$, Paul HK Jap ${ }^{2}$ and \\ Fred JJM van de Molengraft ${ }^{3}$ \\ ${ }^{1}$ Department of Biochemistry, Nijmegen Center for Molecular Life Sciences, University Medical Center, \\ Nijmegen, The Netherlands; ${ }^{2}$ Department of Anatomy, University Medical Center, Nijmegen, \\ The Netherlands and ${ }^{3}$ Department of Pathology, Rijnstate Hospital, Arnhem, The Netherlands
}

\begin{abstract}
A murine monoclonal antibody (MoAb CO-TL1, IgG1) has been raised by differential screening of hybridoma supernatants on sections of human large and small intestines, followed by screening on colon adenomas as well as on colorectal carcinomas. In both paraffin sections and cryostat sections, the antibody stained strongly all cell types in adult, neonatal and fetal human colorectal epithelium, that is, the goblet cells, the columnar cells and the endocrine cells. No staining was observed in the remaining parts of the normal gastrointestinal tract and other tissues. As revealed by immuno electron microscopy the epitope was present in the apical and basolateral cell membranes, the Golgi complex, secretory vesicles of goblet and columnar cells, and also in granules of the endocrine cells. The epitope in colorectal tissue sections was resistant to the deglycosylation enzymes neuramidase, diastase and hyaluronidase indicating its proteinaceous nature. This colorectal antigen remained expressed in $100 \%$ of colorectal adenomas $(n=39)$ and $86 \%(n=29)$ of colorectal carcinomas. The expression was reduced in undifferentiated carcinomas. The CO-TL1 antibody detected also most other gastrointestinal adenocarcinomas and a few carcinomas of the ovary, uterus, breast, gallbladder and pancreas. However, it never detected carcinomas derived from the thyroid, lung, liver, bladder, kidney, prostate, testis, serous membranes of body cavities and skin. A wild-type variant protein of $>300 \mathrm{kDa}$ of the colorectal antigen was identified in normal colorectal epithelium. In colorectal tumours, however, two tumour variant forms were found of 160-200 and 115-140 kDa, respectively. Our data indicate that this new MoAb CO-TL1 can be considered as a useful marker, which identifies normal colorectal epithelium and gastrointestinal tumours and especially colorectal tumours with high accuracy and excludes tumours originated from thyroid, lung, liver, bladder, kidney, prostate, testis, mesothelium and skin.
\end{abstract}

Laboratory Investigation (2004) 84, 1160-1173, advance online publication, 14 June 2004; doi:10.1038/labinvest.3700130

Keywords: colorectal tissue; immuno-electron microscopy; immunohistochemistry; monoclonal antibodies; neoplasm; tumour marker

Colorectal cancer is a major cause of mortality in the Western world, and is thought to develop through the 'adenoma-to-carcinoma sequence' model, resulting from accumulation of successive, step-wise mutations in oncogenes and tumour suppressor genes (K-ras, p53, DCC, APC, hMSH2, CTNNB1, $M A D H 4 / S M A D 4$ and TGFBR2) leading to loss of genomic stability, increased mutation rates and nonfunctional truncated APC proteins, aberrant glycosylation, altered expression levels of (glyco)

Correspondence: Dr GB ten Dam, PhD, Department of Biochemistry, Nijmegen Center for Molecular Life Sciences, University Medical Center Nijmegen, Geert Grooteplein 26-28, 6525 GA Nijmegen, The Netherlands.

E-mail: G.tenDam@ncmls.kun.nl

Received 27 August 2003; revised 15 April 2004; accepted 20 April 2004; published online 14 June 2004 proteins, and finally resulting in transformed cells with an abnormal behaviour and intercellular communication as reviewed by Grady and Markowitz. ${ }^{1}$ As a result of these mutations and subsequent transformations 'unique' tumour antigens have emerged, to which monoclonal antibodies were generated $^{2,3}$ like the Adnab-9 antibodies, ${ }^{4}$ DAS-1 antibody, ${ }^{5}$ G47 antibodies. ${ }^{6}$ On the other hand, monoclonal antibodies to antigens that are not unique but common for both the normal cell type and the derived tumour cells might serve equally well as markers. Antibodies to intermediate filaments (vimentin, neurofilament, keratin) have been amply used to trace tissue-specific origin of tumours. We and others have shown previously that combinatorial application of anti-keratin 7 and broadspectrum anti-keratin monoclonal antibodies, in particular anti-keratin 20 antibodies, is very helpful 
for discrimination between carcinomas derived from small and large intestine (keratin 7-negative) and ovarian cancer (keratin 7-positive), but also for appreciating prognosis of the disease. ${ }^{7-11} \mathrm{MoAb}$ 5E9, as a marker for merely normal colonic crypt cells, has been suggested to be associated with poor prognosis when expressed at high levels in colorectal cancer cells. ${ }^{12}$ Antibodies to wild type and mutant or truncated forms of APC appeared useful tools to define the progression of colorectal malignancy. ${ }^{13}$ The availability of monoclonal antibodies to various types of mucins (HGM, PGM, MUC1-7 and others) has greatly facilitated the identification of different gastrointestinal cell phenotypes and origin of digestive tract tumours, ${ }^{14}$ for example, MUC2 as a colorectal-specific $520 \mathrm{kDa}$ glycoprotein in goblet cells. ${ }^{15}$

In this study, we describe the development of a new monoclonal antibody (CO-TL1) that reacted tissue-specifically with a colorectal antigen expressed in all three normal cell types (goblet, columnar and endocrine). The CO-TL1 defined antigen retained its expression in colorectal tumour and gained expression in other gastrointestinal tumours. We report here a detailed immunohistochemical and immunoelectron microscopical characterization of the localization of the antigen.

\section{Materials and methods}

\section{Tissues}

Normal and neoplastic adult human tissues were obtained by autopsy and/or by surgery, snap-frozen in liquid nitrogen and stored at $-80^{\circ} \mathrm{C}$ until use. Frozen sections $(4-7 \mu \mathrm{m})$ were cut, air dried and used for immunohistochemical analysis without fixation. In addition, immunohistochemical assays were carried out on $6 \mu \mathrm{m}$ thick paraffin sections (Paramat, Gurr) prepared from human tissues that were fixed in $4 \%$ neutral-buffered formalin. Paraffin-embedded samples from normal fetal human tissues (aged 11-12 weeks) and neonatal from autopsies 8 to $12 \mathrm{~h}$ postmortem were used. All materials were obtained with informed consent and/or permission of the ethical commission.

Adult animal tissue samples for immunohistochemical analysis were obtained from Balb/c mice, Wistar rats and New Zealand rabbits, and were processed similarly for both cryostat sections and paraffin sections.

\section{Cell Lines and Antibodies}

All cell lines were grown in RPMI 1640-based culture medium (Gibco BRL, Life Technologies, Breda, The Netherlands) supplemented with 10$15 \%$ Fetal Calf serum (FCS, Gibco BRL), $50 \mathrm{U} / \mathrm{ml}$ penicillin, $50 \mu \mathrm{g} / \mathrm{ml}$ streptomycin, at $5 \% \mathrm{CO}_{2}$. Some cell lines were also grown as xenografts in nude ${ }^{-/}$ Balb/c mice, 6-10 weeks of age. Formalin-fixed, paraffin sections of xenografts were kindly provided by Dr W Dinjens (Deptartment of Pathology, Erasmus University, Rotterdam, The Netherlands). The following human colon carcinoma cell lines were investigated for reactivity with monoclonal antibody CO-TL1: SW480, HT-29/18N2, HT-29/D4, LS174 T (American Type Cell Culture, ATCC, Rockville, MD, USA); 5583-E as well as 5583-S were kindly supplied as xenografts by Dr W Dinjens; the colon carcinoma cell line variants HT29-G, HT29-MTX, HT29-FU, as well as Caco-2 (ATCC) were kindly provided by Dr J Fransen (Deptartment of Cell Biology, NCMLS, UMC Nijmegen, The Netherlands). The ovarian carcinoma cell line NIH-OVCAR 3 was obtained from the ATCC (Rockville, MD, USA) and NIH-OVCAR 4 was obtained from Dr T Hamilton (Fox Chase Institute, Philadelphia, PA, USA). Cells were grown in tissue culture flask or on coverslips in 24-well plates (Costar, Cambridge, MA, USA), and examined for reactivity with CO-TL1 antibody both at stages of nonconfluence and (over)confluence. The epithelial origin of normal human tissues and carcinomas were routinely assayed immunohistochemically with the broad-spectrum anti-keratin monoclonal antibody OV-TL12/5 (recognizing keratin 5, 7, 14 and 19) in frozen sections and the MoAb OV-TL12/30 that recognizes keratin 7 in both paraffin and cryostat sections. ${ }^{16}$ Keratin 7 is known to be absent in digestive tract epithelium. ${ }^{16,10}$ An affinity purified polyclonal antibody against sucrase-isomaltase (SI) as a marker for small intestinal absorptive cells ${ }^{17}$ was kindly provided by Dr J Fransen.

\section{Preparation of Hybridomas}

Snap-frozen well-differentiated colorectal carcinoma tissue (CEA-positive as assayed with the antibody BW431/31,18,19 and keratin 7-negative) was homogenized in PBS on ice $(0.29 \mathrm{~g}$ of tissue $/ \mathrm{ml})$, cell and tissue debris was spun down at $2000 \mathrm{rpm}$. Balb/ c mice were immunized intraperitoneally (without the use of adjuvants) with $300 \mu$ l of colorectal carcinoma tissue homogenate, 6 times within a period of 13 weeks. Four days after the last injection splenic B cells were fused with mouse myeloma cells SP2/0-Ag14 (ATCC) according to procedures as described previously. ${ }^{20}$ Hybridoma supernatants were initially screened by immunofluorescence on frozen sections from two different colon carcinoma patients. Candidates for further cloning were chosen from those giving a clear positive staining with epithelial cells but negative staining in all other tissue cell types. The monoclonal antibodies were isotyped using the mouse isotyping kit (Gibco BRL), according to the manufacturer's instructions.

\section{Immunohistochemical Assays}

The binding of monoclonal antibodies to methanolfixed cells and unfixed tissue sections were assayed 
by the indirect immunofluorescence assay as described previously. ${ }^{20}$ The immunoperoxidase assay on paraffin sections was carried out after pretreatment of the sections with pepsin as described previously. ${ }^{16}$ Sections were incubated with the primary antibody CO-TL1 (hybridoma supernatant, 1:2 diluted in PBS-tween-20 (0.05\%, PBST) for $1 \mathrm{~h}$, followed by repeated washing with PBST and subsequent incubation with rabbit anti-mouse (RAM)-peroxidase (1:100, Dakopatts, Glostrup, Denmark). Peroxidase activity was revealed with 4amino-9-ethylcarbazole (AEC, Alderich Chemical Comp. St Louis, MO, USA) and counterstained with Mayer's haematoxylin (Brunschwig Chemie, Amsterdam, The Netherlands). Sensitivity for neuramidase treatment $\left(0.01 \%\right.$ for $3 \mathrm{~h}$ at $40^{\circ} \mathrm{C}$, Sigma, St Louis, MO, USA), diastase $\left(0.1 \%\right.$ for $1 \mathrm{~h}$ at $37^{\circ} \mathrm{C}$, Sigma) and hyaluronidase treatment $(0.1 \%$ for $1 \mathrm{~h}$ at $37^{\circ} \mathrm{C}$, Sigma) was assayed according to standard procedures.

\section{Immunoelectron Microscopy}

For immunoelectron microscopic investigations, normal ileal and colorectal tissues obtained from biopsies or surgery were shortly rinsed in physiological saline and fixed immediately by immersion for $2 \mathrm{~h}$ in a mixture of $2 \%$ paraformaldehyde and $0.1 \%$ glutaraldehyde in $0.1 \mathrm{M}$ phosphate buffer ( $\mathrm{pH} 7.3$, $4^{\circ} \mathrm{C}$ ) and subsequently stored in $1 \%$ paraformaldehyde in the same buffer. Ultra-thin sections were cut using the Reichert Ultracut $S$ and incubated with the primary antibody CO-TL1, followed by RAM-IgG, subsequently incubated in a Protein A-gold (10 nm) solution (Aurion, Wageningen, The Netherlands). As controls served omission of CO-TL1 antibody and the use of the anti-sucrase-isomaltase antibody (SI). The sections were examined and photographed in a Philips EM 301 electron microscope.

\section{Western Blotting}

Tissue samples from the mucosal layer of normal human colon and ileum, and from tumour cell lines, were solubilized in lysis buffer $\left(30 \mathrm{~min}\right.$ at $0^{\circ} \mathrm{C}, \mathrm{pH}$ 8.1, $100 \mathrm{mM} \mathrm{Na} \mathrm{HPO}_{4}, 1 \% \mathrm{NP}-40$ ) containing the protease inhibitors phenylmethylsulphonylfluoride (PMSF) $80 \mu \mathrm{g} / \mathrm{ml}$; leupeptin $10 \mu \mathrm{g} / \mathrm{ml}$; aprotinin $10 \mu \mathrm{g} / \mathrm{ml}$; pepstatin $10 \mu \mathrm{g} / \mathrm{ml}$; all from Sigma) and subsequently centrifuged in an Eppendorf centrifuge for $15 \mathrm{~min}$ at maximum speed. The homogenate and supernatant fraction were diluted and heated at $100^{\circ} \mathrm{C}$ for $3 \mathrm{~min}$ in $2.3 \%$ SDS-sample-buffer and separated on $8 \%$ sodium dodecyl sulphate-(SDS) polyacrylamide gel under both nonreducing and reducing ( $0.1 \mathrm{M} \beta$-mercaptoethanol) conditions in a Mini Protean II apparatus (Bio-Rad, Richmond, CA, USA). After electrophoresis, proteins were transferred to a nitrocellulose membrane (NC) (Schleicher \& Schuell, Dassel, Germany). The a-specific binding sites were blocked, for $2 \mathrm{~h}$ with blocking buffer $(2 \%$ BSA, in PBST; or alternatively in sterilized nonfat milk). Blots were incubated with CO-TL1 antibody (hybridoma supernatant, 1:10 dilution) for $1 \mathrm{~h}$, washed 3 times with PBST, incubated with goat anti-mouse Ig-peroxidase (1:100 in PBS, Dakopatts, Glostrup, Denmark) for $1 \mathrm{~h}$ in the presence of $1 \%$ normal rabbit or goat serum, and subsequently washed 3 times with PBST and PBS. The luminol-based enhanced ECL method (Amersham Int., UK) for autoradiographic visualization of the peroxidase activity on blots was used exactly according to the manufacturer's procedures. Prestained molecular weight markers (Bio-Rad) ranging from 205 to $6.5 \mathrm{kDa}$ were used as reference.

\section{Results}

\section{Development of Antibody CO-TL1}

In the search for markers that could be helpful in differential diagnosis of colorectal tumours and ovarian cancer tumours, supplementary to the previously developed anti-keratin $(5,7,14,19)$ monoclonal antibodies (OVTL 12/5), the keratin-7-specific antibody (OVTL12/30) and the ovarian tumour marker OVTL3, we now developed colorectalspecific antibodies by immunizing mice with an extract of a well-differentiated colorectal carcinoma (CEA +, keratin 7-). The hybridoma supernatants were initially selected by positive staining with both normal and malignant colorectal epithelium, and negative reactivity with all other tissue components of colorectal tissue. In that early stage of the screening hybridomas were also selected for absence of reactivity, both on normal small intestinal tissue as well as on ovarian carcinoma (one tissue sample each). One of the selected and repeatedly recloned hybridoma cell lines was designated CO-TL1 and produced a monoclonal antibody of the IgG1 class (kappa-chain).

\section{Reactivity with Normal Adult Human Tissues}

Pretreatment of formalin-fixed, paraffin tissue sections with pepsin demasked the epitope recognized by CO-TL1 in frozen sections to such an extent that the peroxidase staining reaction appeared identical and equally strong in both frozen sections and in paraffin sections of all tissues investigated. Table 1 summarizes therefore the staining data of both paraffin and frozen tissue sections.

Table 1 shows that strong staining was found in (mucous) goblet cells, nonmucous columnar cells and endocrine cells in the large intestine (Figure 1a-c), but not in any other cell of the lining epithelium of the digestive tract (eg small intestine in Figure 1f). Positively stained large granules were found in the supranuclear area (Figure 1a) of goblet cells. In columnar cells label was distinctly seen as 
Table 1 Reactivity of CO-TL1 monoclonal antibodies in normal adult human tissues

\begin{tabular}{|c|c|c|}
\hline Tissues & CO-TL 1 & $O V-T L 12 / 30$ \\
\hline \multicolumn{3}{|l|}{ Tongue } \\
\hline Squamous epithelium & - & - \\
\hline Taste buds & - & ++ \\
\hline Glands (salivary) & $+/-^{\mathrm{a}, \mathrm{b}}$ & ++ \\
\hline \multicolumn{3}{|l|}{ Oesophagus } \\
\hline Squamous epithelium & - & - \\
\hline Glands & $+/-^{\mathrm{a}, \mathrm{b}}$ & + \\
\hline Stomach & - & $-{ }^{\mathrm{b}}$ \\
\hline Duodenum & - & - \\
\hline Jejunum & - & - \\
\hline Ileum & - & - \\
\hline \multicolumn{3}{|l|}{ Colorectal epithelium } \\
\hline Nonmucous (columnar) cells & ++ & - \\
\hline Mucous (goblet) cells & ++ & - \\
\hline Endocrine cells & ++ & - \\
\hline Squamous epithelium & - & - \\
\hline \multicolumn{3}{|l|}{ Liver } \\
\hline Hepatocytes & - & - \\
\hline Bile ducts & - & ++ \\
\hline \multicolumn{3}{|l|}{ Pancreas } \\
\hline Acini & - & - \\
\hline Ducts & - & ++ \\
\hline Islets of Langerhans & - & - \\
\hline Gallbladder & $-{ }^{\mathrm{b}}$ & ++ \\
\hline \multicolumn{3}{|l|}{ Lung } \\
\hline Bronchial epithelium & $t^{\mathrm{a}}$ & ++ \\
\hline Alveoli & - & ++ \\
\hline Glands & $-{ }^{\mathrm{b}}$ & ++ \\
\hline \multicolumn{3}{|l|}{ Prostate } \\
\hline Glandular cells & - & $+^{\mathrm{C}}$ \\
\hline Ducts & - & ++ \\
\hline \multicolumn{3}{|l|}{ Testis } \\
\hline Seminiferous tubules & - & - \\
\hline Epididymis & - & ++ \\
\hline Penis, urethra & $+/-^{a}$ & ++ \\
\hline Ovary & - & - \\
\hline Surface epithelium & - & ++ \\
\hline Granulosa cells & - & $+1-$ \\
\hline Fallopian tube & $+/-^{\mathrm{c}}$ & ++ \\
\hline \multicolumn{3}{|l|}{ Uterine corpus } \\
\hline Glandular epithelium & - & ++ \\
\hline Decidual epithelium & - & ++ \\
\hline \multicolumn{3}{|l|}{ Cervix } \\
\hline Glandular epithelium & $-{ }^{\mathrm{b}}$ & ++ \\
\hline Squamous epithelium & - & - \\
\hline \multicolumn{3}{|l|}{ Placenta } \\
\hline Cytotrophoblast & - & ++ \\
\hline Syncytiotrophoblast & - & + \\
\hline \multicolumn{3}{|l|}{ Vagina } \\
\hline Squamous epithelium & - & - \\
\hline Mammary gland & - & ++ \\
\hline \multicolumn{3}{|l|}{ Kidney } \\
\hline Tubular system & - & $++^{\mathrm{d}}$ \\
\hline Pyelum & - & ++ \\
\hline
\end{tabular}

Table 1 Continued

\begin{tabular}{|c|c|c|}
\hline Tissues & CO-TL 1 & OV-TL12/30 \\
\hline Ureter & - & ++ \\
\hline \multicolumn{3}{|l|}{ Bladder } \\
\hline Urothelium & $+/-^{\mathrm{a}}$ & ++ \\
\hline \multicolumn{3}{|l|}{ Skin } \\
\hline Epidermis & - & - \\
\hline Eccrine sweat glands & - & ++ \\
\hline Sebaceous glands & - & - \\
\hline \multicolumn{3}{|l|}{ Lymphoid organs } \\
\hline Spleen, lymph nodes, tonsil & - & - \\
\hline Thymus & - & - \\
\hline Hassall bodies & $-{ }^{\mathrm{b}}$ & - \\
\hline Bone marrow smears & - & - \\
\hline Thyroid gland & $-{ }^{\mathrm{b}}$ & $+^{\mathrm{c}}$ \\
\hline Parathyroid gland & - & nd \\
\hline Adrenal gland & - & - \\
\hline Brain tissue, ependyma & - & - \\
\hline Eye (lens, cornea, retina) & - & - \\
\hline Muscle tissue (smooth, striated) & - & - \\
\hline Blood cells & - & - \\
\hline Nerve tissue & - & - \\
\hline Connective tissue & - & - \\
\hline Mesothelium & $-^{\mathrm{a}, \mathrm{e}}$ & + \\
\hline
\end{tabular}

The reactivity of CO-TL1 antibody was analysed on both paraffin sections and snap-frozen unfixed section, and no differences were noticed. Reactivity is indicated by ++, very strong; +, strong; +/-, weak; -, no staining. The number of investigated samples varied from three to five different normal tissue biopsies. ND, not done.

${ }^{\mathrm{a}}$ Focal positive staining.

${ }^{\mathrm{b}}$ Sporadic positive cells $(<5 \%)$.

${ }^{\mathrm{c}}$ Heterogeneous staining.

${ }^{\mathrm{d}}$ Proximal tubules were negative.

${ }^{\mathrm{e}}$ In some samples (5/10), the mesothelium was positive in segments of the lining.

basolateral and apical membrane staining as well as a granular supranuclear aggregation (Golgi area) (Figure 1b). In endocrine cells, the CO-TL1-positive granules were found in the subnuclear area (Figure 1c, arrows). Essentially, all colon epithelial cell types were stained with the CO-TL1 antibody.

Sporadically, some minor nests of CO-TL1-stained mucous cells were found in mixed glands of tongue and some other organs (Table 1), for example, intermingled between negative bronchiolar lining epithelium of the lung (Figure 1e). Essentially, all other tissues were completely negative, and these observations illustrate the colorectal specificity of the marker antibody in both frozen and paraffinembedded sections.

When paraffin (or frozen) sections of colorectal tissue were pretreated with neuramidase or hyaluronidase combined with pepsin predigestion, the reactivity with CO-TL1 remained unimpaired positively, indicating that the recognized antigen epitope was probably a (glyco)protein rather than a carbohydrate moiety. 

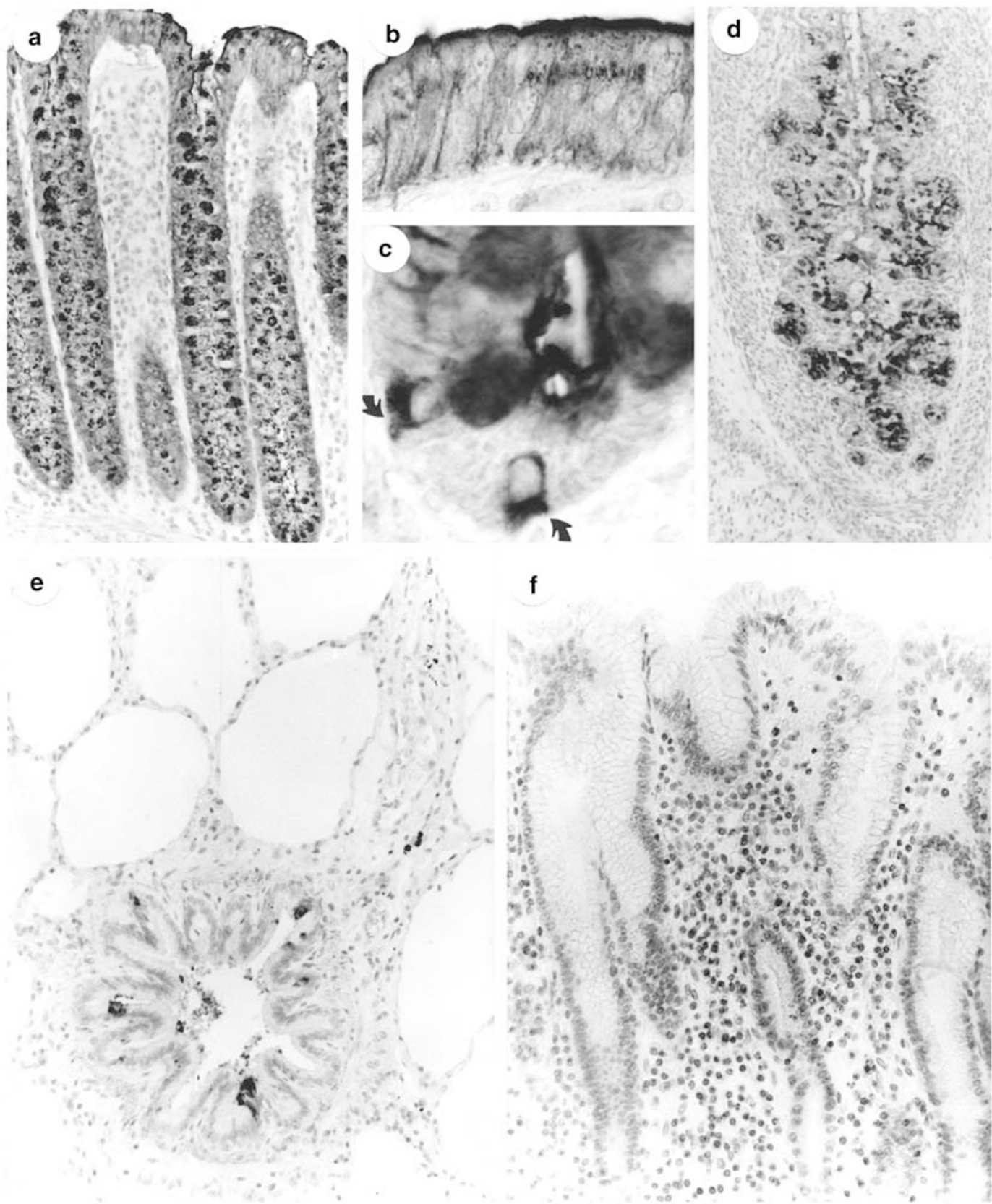

Figure 1 (a)-(f) Immunoperoxidase staining pattern of CO-TL1 antibody on paraffin-embedded human tissues. (a)-(c) Adult human colonic epithelium. Essentially, all cell types are CO-TL1 positive, showing both cytoplasmic supranuclear staining (a) as well as apical, Golgi and basolateral membrane staining (b). Endocrine cells were strongly stained subnuclearly (c). Fetal human colon stained positive with antibody CO-TL1 (d). Negative lung alveoli, with focally positive small nests in bronchiolar epithelium (e). Negative CO-TL1 reaction with ileal epithelium (f). (g)-(m) Immunoelectron microscopical localization of CO-TL1 antibody in normal human colonic epithelium. Strong CO-TL1 antibody gold labelling was associated with the apical microvilli $(\mathrm{g})(\times 35000)$, with basolateral interdigitations (i) except for the junctional complexes $(\times 10000)$, with trans-faces of the Golgi apparatus $(\mathbf{k})$ but not with the cis-faces $(\times 25000)$, with the grey peripheral $\mathrm{rim}(\mathbf{h})$ (proteins) of electron-lucent vesicle $(\mathbf{\nabla} ; \times 5000)$. The light mucin areas $(* ;$ inset $\times 40000)$ in a large electron-lucent vesicles are negative. The small electron-dense vesicles $(\searrow$ ) react homogeneous positively. Endocrine granules stained positively $(\mathrm{j})(\times 10000)$. Positive control labelling of the surface of jejunal microvilli with sucrose-isomaltase (SI) antibody (l) $(\times 80000)$ was found but no CO-TL1 staining of the jejunal microvilli $(\mathbf{m})(\times 80000)$. $(\mathbf{n})-(\mathbf{t})$ Immunoperoxidase staining pattern of COTL1 antibody in paraffin-embedded human colorectal tumours. Normal colorectal epithelium with granular CO-TL1 deposits in goblet cells (n). Colorectal adenomas with mild dysplasia (o) and nearly normal CO-TL1 staining; moderate dysplasia (p)-(q) with less cytoplasmic and more membranous CO-TL1 labelling; moderate dysplasia (r) with CO-TL1 labelling confined to the apical, lumenal cell site. Well-differentiated mucinous carcinoma of the colon with strong staining of both the cystic pool of mucin and carcinoma cells (s). In poorly differentiated colorectal carcinomas, the CO-TL1 staining (both membrane and cytoplasm) was reduced to small irregular focal glandular structures (t). (u)-(v) Immunofluorescence CO-TL1 staining of the human colorectal tumour cell lines. Monolayer of E-5583 in culture: weak granular staining of CO-TL1 in nonconfluent cells, but strong fluorescence in "confluent" clusters of cells growing in threedimensional domes (u). Positive immunoperoxidase staining of paraffin-embedded xenograft of LS174 T colon tumour cells (v). Adjacent liver cells are negative. 

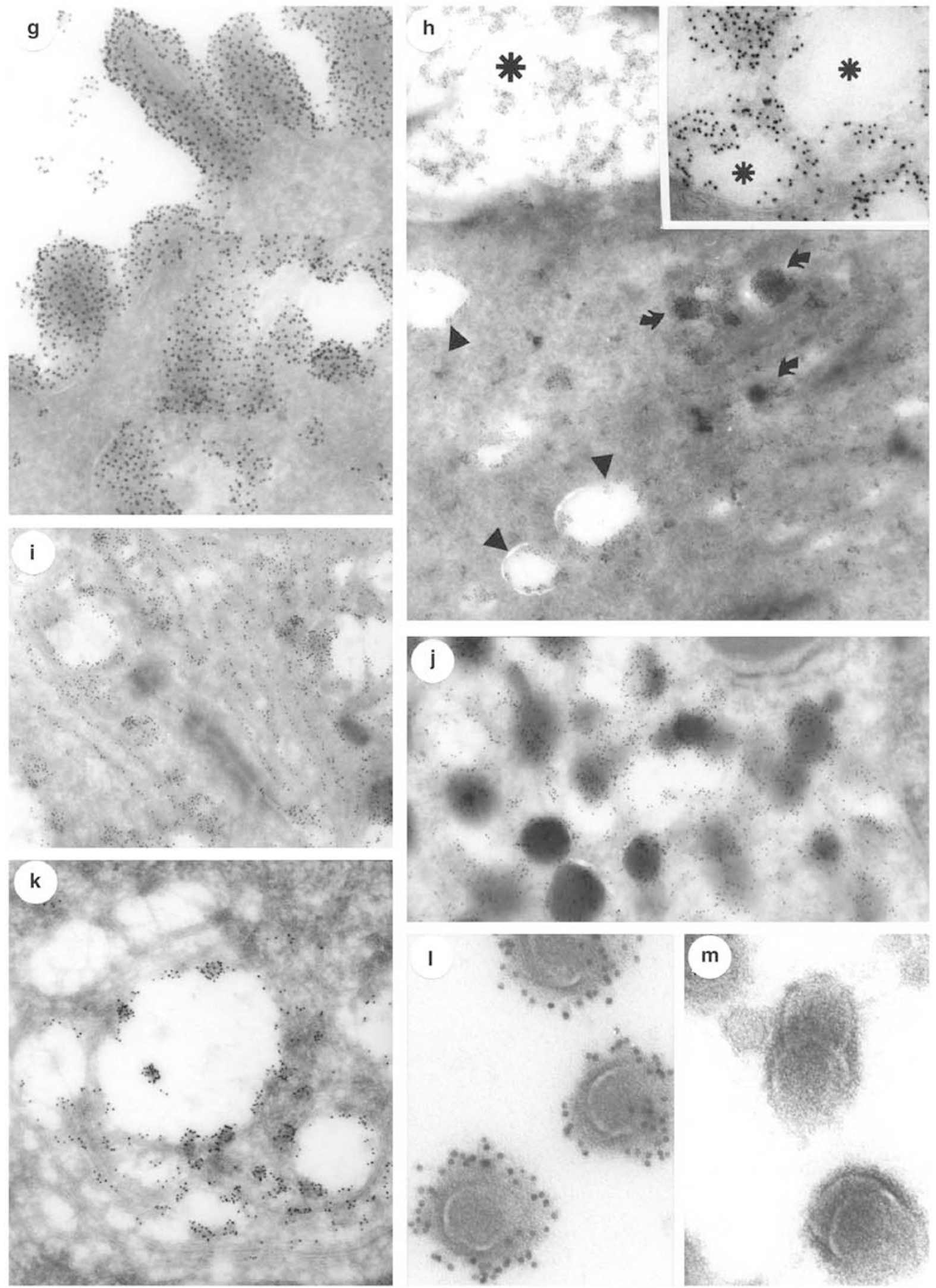

Figure 1 Continued. 

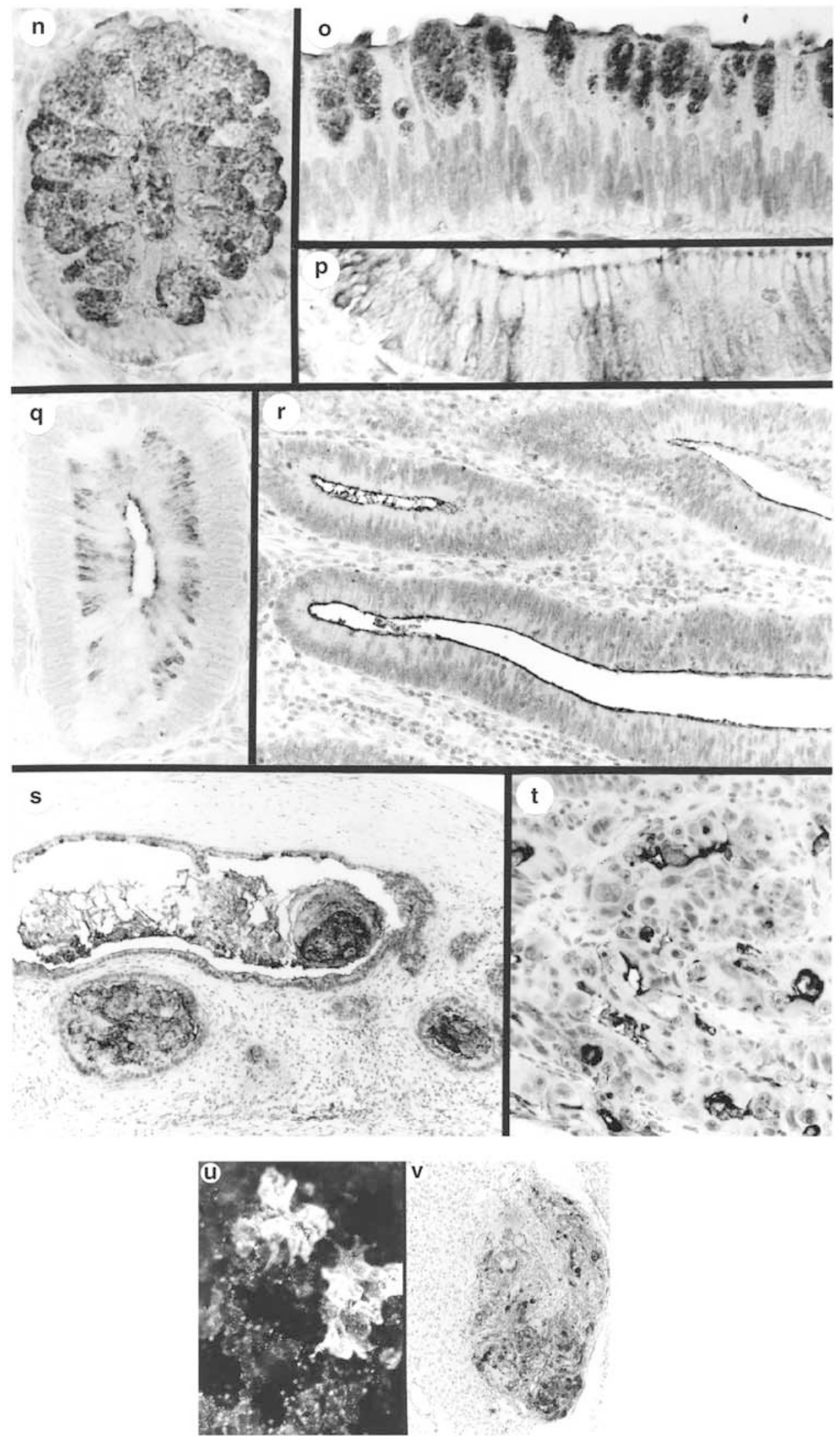

Figure 1 Continued. 


\section{Fetal and Neonatal Human Tissue}

The expression of the CO-TL1 defined antigen was investigated in a limited number $(n=3)$ of paraffinembedded, fetal tissue specimens (11-12 weeks of age), as well as in neonatal specimens $(n=2)$. Strong expression was found mainly in the apical, lumenal side of colorectal epithelial cells (Figure 1d), while all other parts of the digestive tract were essentially negative. In neonatal colonic epithelium, the staining pattern was identical to adult colorectal epithelium, showing labelling of mucous, nonmucous and endocrine cells in both the cytoplasm and at the cell membrane. No expression in other fetal organs was found except for positive staining in retracted and desquamating peridermal cells of the fetal skin and the mucous cells in the conjunctival fornix of the eye.

\section{Immunoelectron Microscopic Localization in Normal Human Colorectal Epithelium}

The specific structures that were stained by the antibody CO-TL1 were further investigated by immunoelectron microscopy on biopsies or surgical samples of human colon and ileum. A polyclonal antibody to sucrase-isomaltase (SI) was used as control, since SI is known to be expressed in adult small intestinal epithelium but not in adult colonic epithelium. ${ }^{17}$ Essentially, all three cell types (goblet cells, columnar cells and endocrine cells) showed strong CO-TL1 immunogold labelling over the entire cell membrane, that is, on the apical microvilli (Figure 1g) and on the basolateral membranes (Figure 1i), with exception of the junctional complexes. In both mucous and nonmucous colonocytes, label was found specifically associated with the trans-faces of the Golgi apparatus but not with the cis-faces (Figure $1 \mathrm{k}$ ). The CO-TL1 antibody reacted with two types of vesicles. In the electron-lucent vesicle type (with a large but variable diameter) the label was found to be associated with the peripheral rim of the vesicle (Figure 1h, arrowheads $\boldsymbol{\Delta} \mathbf{\Delta}$ ). In the smaller-sized electron-dense vesicles the label was found homogeneously distributed within the vesicle (Figure $1 \mathrm{~h}$, arrows $\lambda \nearrow$ ). The mucous cells contain both types of vesicles, with the majority of large electron-lucent vesicles while the nonmucous cells only contain the second type of smaller electron-dense vesicles. Vesicles were sometimes found fused with the (apical and basolateral) cell membranes as well as with endosomes. In some but not all lysosomes distinct label was found. The CO-TL1 antibody label was associated preferentially with the (proteinaceous) electron-grey substance in condensing vacuoles and large fused droplets in the apical site of the mucous cell (Figure 1h), while the (mucous) electron-light areas (asteriks $* *$ ) were hardly labelled with the antibody (inset). No label was found, however, in rough endoplasmic reticulum, mitochondria and lipid droplets. The endocrine cells showed labelling both in Golgi areas and in endocrine granules
(Figure 1j). The apical and basolateral cell membranes were usually labelled less intense than the nonendocrine colon cells. No other organelles were labelled. While the control antibody for SI in ileumstained microvilli (Figure 1l) and lysosomal structures (not shown), no CO-TL1 labelling was found in any of the epithelial cell types of the ileum (Figure 1m). Reversibly, none of the colonic epithelial cells were stained with antibodies to SI.

\section{Animal Species}

The analysis of the staining pattern of the antibody CO-TL1 on sections of animal tissues was mainly confined to gastrointestinal samples in mice, rats and rabbits. CO-TL1 antibody reacted strongly with the goblet cells in paraffin sections of colon of rabbit, rat and mouse. The cryptic columnar cells in the colorectal tissues were well stained but the columnar cells near the surface lining were stained weakly or negatively (data not shown). While the rat and rabbit small intestinal epithelia were CO-TL1 negative, mice small intestinal epithelium was stained positively predominantly in the crypts, but weak staining of the Golgi area was observed in the mouse columnar cells in the villi. The epithelial cells of the stomach and oesophagus of the same mice were negative.

\section{Human Colon Tumours}

Since, in pilot experiments on 10 colon adenomas and 10 colon carcinomas the CO-TL1 antibody immune reactivity in unfixed cryostat sections was similar to the staining pattern in pepsin predigested paraffin sections, data summarized in Table 2 were confined to the paraffin sections. In all, $100 \%$ of all colon adenomas showed strong, fine granular staining with the antibody CO-TL1. While in normal epithelial cells (Figure 1n) label was found both on all membranes and in coarse cytoplasmic granules, the expression of the antigen in adenomatous cells varied from nearly normal cytoplasmic expression (Figure 1o) to overall-membrane expression (Figure $1 \mathrm{p})$, an intermediate variant of surface membrane and Golgi area expression (Figure 1q) as well as apical membrane expression (Figure 1r). In colon carcinomas, the CO-TL1 staining was usually confined to apical and lumenal cell side. In mucinous colon carcinomas, strong CO-TL1 antibody staining was found in coarse granules in intercellular cystic pools (Figure 1s). In poorly differentiated and undifferentiated tumours, the staining was diminished to small focal areas (Figure 1t).

\section{Human Tumour Cell Lines and Xenografts}

None of the variants of the HT-29 colon carcinoma cell line, except for the xenograft of the $18 \mathrm{~N} 2$ 
Table 2 Reactivity of CO-TL1 monoclonal antibodies with human colon tumours ${ }^{\mathrm{a}}$

\begin{tabular}{|c|c|c|}
\hline Tissues & $\begin{array}{l}\text { No. of CO-TL1 } \\
\text { positive samples }\end{array}$ & Localization \\
\hline \multicolumn{3}{|l|}{ Colon adenomas } \\
\hline Tubular & $16 / 16++$ & Lumenal \\
\hline Tubulovillous and & $23 / 23++$ & Lumenal \\
\hline $\begin{array}{l}\text { villous } \\
\text { (Total benign) }\end{array}$ & $(39 / 39,100 \%)^{b}$ & \\
\hline \multicolumn{3}{|l|}{ Colon carcinomas ${ }^{b}$} \\
\hline Well differentiated & $\begin{array}{l}11 / 12++ \\
1 / 12+/-\end{array}$ & Apical, lumenal \\
\hline $\begin{array}{l}\text { Moderately } \\
\text { differentiated }\end{array}$ & $8 / 10++$ & Focal, lumenal \\
\hline $\begin{array}{l}\text { Poorly } \\
\text { differentiated }\end{array}$ & $\begin{array}{c}2 / 10+/- \\
1 / 7++\end{array}$ & Focal \\
\hline & $\begin{array}{c}2 / 7+/- \\
4 / 7-\end{array}$ & Focal \\
\hline (Total malignant) & $(25 / 29,86 \%)^{\mathrm{c}}$ & \\
\hline \multicolumn{3}{|l|}{ Miscellaneous } \\
\hline Juvenile & $2 / 2++$ & \\
\hline $\begin{array}{l}\text { hamartomatous } \\
\text { colon polyp }\end{array}$ & & \\
\hline Inflammatory & $1 / 1++$ & \\
\hline cystic colitis & & \\
\hline Jejunal Peutz- & $2 / 2-$ & \\
\hline Jeghers polyp & & \\
\hline Colorectal & $2 / 7++$ & \\
\hline $\begin{array}{l}\text { Appendix } \\
\text { carcinoid }\end{array}$ & $2 / 7++^{\mathrm{d}}$ & \\
\hline \multicolumn{3}{|c|}{ Colon carcinoma cell lines } \\
\hline Сaco-2 & $\begin{array}{c}-\left(<5 \%+^{\mathrm{e}}\right) \\
\text { in culture }\end{array}$ & \\
\hline Colo-320 & - , in culture & \\
\hline HT29 & - , in culture & \\
\hline HT29-MTX & - , in culture & \\
\hline HT29-FU & - , in culture & \\
\hline HT29-18N2 & $++(20 \%)$, xenograft & \\
\hline HT29-D4 & - , xenograft & \\
\hline 5583-E & $++(75 \%)$, xenograft & \\
\hline $5583-\mathrm{E}$ & $\begin{array}{c}-, \text { nonconfluent } \\
\text { culture }\end{array}$ & \\
\hline $5583-\mathrm{E}$ & $\begin{array}{c}\text { ++ }(75 \%) \text {, confluent } \\
\text { culture }\end{array}$ & \\
\hline $5583-S$ & $++(25 \%)$, xenograft & \\
\hline $\mathrm{LS} 174 \mathrm{~T}$ & $\begin{array}{c}++(50 \%), \text { xenograft } \\
\text { liver metastasis }\end{array}$ & \\
\hline SW480 & $\begin{array}{l}++(50 \%), \text { in culture } \\
\text { and xenograft }\end{array}$ & \\
\hline
\end{tabular}

${ }^{\mathrm{a}}$ The immunohistochemical assays were carried out on paraffin sections.

${ }^{\mathrm{b}}$ Included five mucinous colon carcinomas.

${ }^{\mathrm{c}}$ Similar results were obtained with unfixed cryostat sections of 10 adenomas and 10 carcinoma samples.

$\mathrm{d}_{\text {The goblet cells stained positive. }}$

${ }^{\mathrm{e}}$ Estimated percentage of positively stained cells in monolayer culture and/or xenograft sections.

subtype, expressed the CO-TL1 defined antigen. Interestingly, the 5583-E cell line, growing as monolayer, became strongly positive for the COTL1 antibody upon reaching confluency in culture, while in nonconfluent cultures most cells were still negative except for small islands of three-dimensional domes (Figure 1u). Both cryostat sections and paraffin sections of 5583-E xenografts in nude -/ $\mathrm{Balb} / \mathrm{c}$ mice showed strong positive staining in most cells (Table 2), while the xenograft of the 'insuspension growing' S-variant cell line showed less reactivity with the antibody. A substantial number of LS174 T xenografted colon carcinoma cells metastasized to the (negative) mouse liver were also found to be strongly positive (Figure 1v). Similar data were found for SW480 cell lines. None of the cell lines expressed keratin 7 (MoAb OV-TL12/30), thus confirming the digestive tract origin of the cell lines, but all were positive with the broad-spectrum monoclonal antibody OV-TL12/5 (keratin 5, 7, 14 and 19). No reactivity was found in ovarian carcinoma cell lines (OVCAR 3, OVCAR 4; data not shown).

\section{Human Tumours}

The specificity of the antibody CO-TL1 was further assayed on 198 noncolon-derived human tumours (Table 3). CO-TL1 antibody did not react with tumours derived from skin, prostate, uterus (leiomyosarcoma and cervix squamous carcinomas), kidney, mesothelium, bladder, liver and thyroid. Traces or focal reactivity in less than $5 \%$ of the cells was found in some tumours derived from lung (squamous cell carcinomas), testis (malignant teratomas, intermediate), and uterus (endometrial adenocarcinomas and malignant mixed Müllerian tumours. Distinct staining was found in only limited numbers of gallbladder adenocarcinomas, cholangiocellular carcinomas, pancreas adenocarcinoma, invasive lobular breast carcinomas, endocervical adenocarcinomas and ovarian adenocarcinomas (serous papillary, endometrioid and borderline). Interestingly, strong staining was observed in large numbers of adenocarcinomas of the digestive tract, other than colon, (oesophagus, stomach and small intestine) suggesting that expression of this normally colon-specific antigen is switched on in adenocarcinomas of the digestive tract.

Table 4 shows that the reactivity of the antibody remained unaltered in liver metastases of colon and ovarian carcinomas, since (almost) all metastasized colon carcinomas stained strongly positive with COTL1 while only limited numbers of the metastasized ovarian carcinomas stained positive (comparable with the nonmetastasized ovarian carcinomas).

\section{Western Blotting}

The MW of the antigen recognized by CO-TL1 was determined by SDS-PAGE followed by Western blotting analysis using as antigen source (solubilized) homogenates and supernatants from human benign and malignant colon and ileum samples as 
Table 3 Reactivity of CO-TL1 monoclonal antibodies with other human tumours

\begin{tabular}{|c|c|c|}
\hline \multirow{2}{*}{$\begin{array}{l}\text { Origin of tumour } \\
\text { Thyroid }\end{array}$} & \multicolumn{2}{|c|}{$\begin{array}{c}\text { No. of CO-TL1-positive } \\
\text { samples }\end{array}$} \\
\hline & & \\
\hline Papillary ca. & $0 / 6++$ & \\
\hline Follicular ca. & $0 / 6++$ & \\
\hline $\begin{array}{l}\text { Undifferentiated ca. } \\
\text { (Total thyroid) }\end{array}$ & $\begin{array}{c}0 / 1++ \\
(0 / 13++)\end{array}$ & \\
\hline \multicolumn{3}{|l|}{ Lung } \\
\hline Squamous cell ca. & $0 / 4++$ & $4^{\mathrm{b}} / 4+/-$ \\
\hline $\begin{array}{l}\text { Adenoca. } \\
\text { - well differentiated }\end{array}$ & - & \\
\hline - moderately & $0 / 1++$ & \\
\hline \multicolumn{3}{|l|}{ differentiated } \\
\hline - poorly differentiated & $0 / 2++$ & \\
\hline Anaplastic large cell ca. & $0 / 3++$ & \\
\hline Bronchiolo-alveolar ca. & $0 / 6++$ & \\
\hline $\begin{array}{l}\text { Small cell anaplastic ca. } \\
\text { (Total lung) }\end{array}$ & $\begin{array}{c}0 / 5++ \\
(0 / 21++)\end{array}$ & \\
\hline \multicolumn{3}{|l|}{ Esophagus } \\
\hline Squamous ca. & $0 / 4++$ & $1^{b} / 4+/-$ \\
\hline Adenoca. & $3 / 5++$ & \\
\hline (Total esophagus) & $(3 / 9++)$ & \\
\hline \multicolumn{3}{|l|}{ Stomach } \\
\hline \multicolumn{3}{|l|}{ Adenoca. } \\
\hline - well differentiated & $1 / 1++$ & \\
\hline - moderately & $2^{\mathrm{c}} / 2++$ & \\
\hline differentiated & & \\
\hline $\begin{array}{l}\text { - poorly differentiated } \\
(+/- \text { signet })\end{array}$ & $7^{\mathrm{c}} / 7++$ & \\
\hline Carcinoid & $0 / 2++$ & \\
\hline (Total stomach) & $(10 / 12++)$ & \\
\hline \multicolumn{3}{|l|}{ Small intestine } \\
\hline Adenoca. & $2 / 2++$ & \\
\hline Carcinoid & $0 / 4++$ & \\
\hline (Total small intestine) & $(2 / 6++)$ & \\
\hline \multicolumn{3}{|l|}{ Liver } \\
\hline Hepatocellular ca. & $0 / 8++$ & \\
\hline (Total liver) & $(0 / 8++)$ & \\
\hline \multicolumn{3}{|l|}{ Gallbladder } \\
\hline Cholangiocellular ca. & $1^{\mathrm{c} / 3++}$ & \\
\hline Gallbladder adenoca. & $3 / 6++$ & \\
\hline (Total gallbladder) & $(4 / 9++)$ & \\
\hline \multicolumn{3}{|l|}{ Pancreas } \\
\hline Adenoca. & $1^{\mathrm{c}} / 10++$ & \\
\hline \multicolumn{3}{|l|}{ Bladder } \\
\hline Urothelial ca. & $0 / 12++$ & \\
\hline \multicolumn{3}{|l|}{ Mesothelium } \\
\hline Malignant mesothelioma & $0 / 11++$ & \\
\hline \multicolumn{3}{|l|}{ Breast } \\
\hline Infiltrating duct ca. & $0 / 5++$ & \\
\hline Medullary ca. & $0 / 5++$ & \\
\hline Invasive lobular ca. & $2 / 5++$ & \\
\hline (Total breast) & $(2 / 15++)$ & \\
\hline \multicolumn{3}{|l|}{ Kidney } \\
\hline Renal cell ca. (Grawitz) & $0 / 3++$ & \\
\hline
\end{tabular}

Table 3 Continued

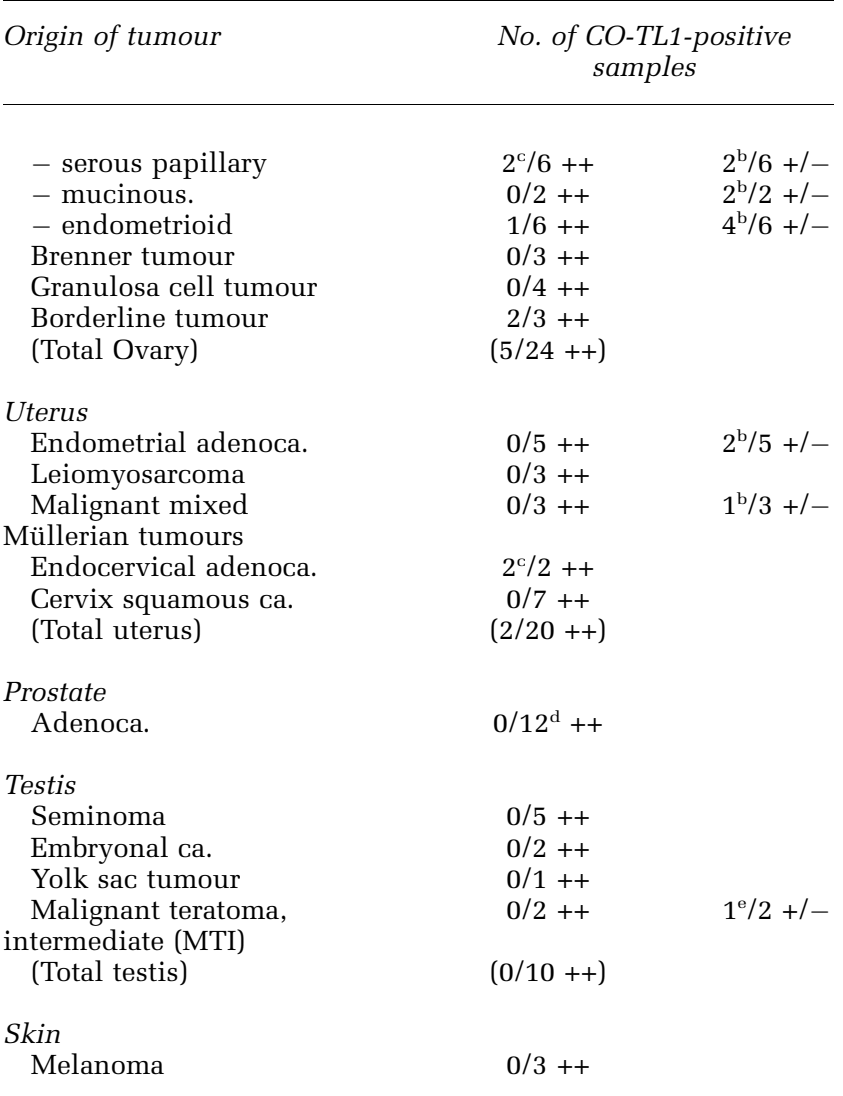

Total number of specimens analysed is 205. Ca.: carcinoma.

${ }^{\mathrm{a}}$ The immunohistochemical assays were carried out on paraffin sections.

$\mathrm{b}_{<5 \%}$ positive tumour cells.

${ }^{\mathrm{C}} 50 \%$ positive tumour cells.

${ }^{\mathrm{d}}$ Primary and metastatic tumours.

${ }^{\mathrm{e}} \mathrm{MTI}$, carcinomatous cells focally positive.

Table 4 Reactivity of CO-TL1 monoclonal antibodies with colon and ovarian metastases ${ }^{\mathrm{a}}$

\begin{tabular}{lcc}
\hline Origin of Tumour & No. of CO-TL1-positive samples \\
\hline $\begin{array}{l}\text { Colon } \\
\text { Liver metastasis }\end{array}$ & $7^{\mathrm{b} / 8++}$ & $1^{\mathrm{c} / 8+/-}$ \\
$\begin{array}{l}\text { Ovary } \\
\text { Liver metastasis }\end{array}$ & $1 / 6++$ & $1^{\mathrm{c} / 6+/-}$ \\
\hline
\end{tabular}

${ }^{\mathrm{a}}$ The immunohistochemical assays were carried out on paraffin sections of core bioptic specimens of the liver.

${ }^{\mathrm{b}}$ Two samples scored $50 \%$ positive tumour cells.

${ }^{\mathrm{c}}<5 \%$ positive tumour cells.

well as cell line SW480. As shown in Figure 2, COTL1 stained predominantly a major broad band of more than $300 \mathrm{kDa}$ found in normal human colorectal mucosa (lane 1). No antigen was found in small intestine (lane 2). Colon carcinoma cell line SW480 in culture (lane 3) and as xenograft (lane 4) showed in addition to the $>300 \mathrm{kDa}$ band a major broad 
doublet band (two bands) between 160 and $200 \mathrm{kDa}$, and a broad band between 115 and $140 \mathrm{kDa}$. Colon carcinoma biopsy (lane 5) and adenomas (lane 6) always showed a pattern similar to that of SW480 cells, that is, three major broad bands with variations in the intensity of the different bands. The molecular weights were not affected by $\beta$-mercaptoethanol treatment of the antigen samples.

Pretreatment with deglycosylating enzymes (endo-F and -H) of both normal and tumour samples, obtained by immunoprecipitation with Protein-A and CO-TL1 antibody, did not result in altered molecular weight (data not shown). This confirmed that the CO-TL1 antigen is rather proteinaceous than carbohydrate-like.

\section{Discussion}

In the search for tumour markers in immunopathology, we have shown previously that monoclonal antibodies to keratin 7 were successfully applied to discriminate for instance between keratin-7-negative tumours of the digestive tract and keratin-7-positive ovarian tumours, while lung tumours could also be subclassified based on keratin 7 expression pattern. ${ }^{10,16,21}$ We now report the development of a new murine monoclonal antibody CO-TL1 (IgG1) that recognizes a colorectal-associated antigen that is

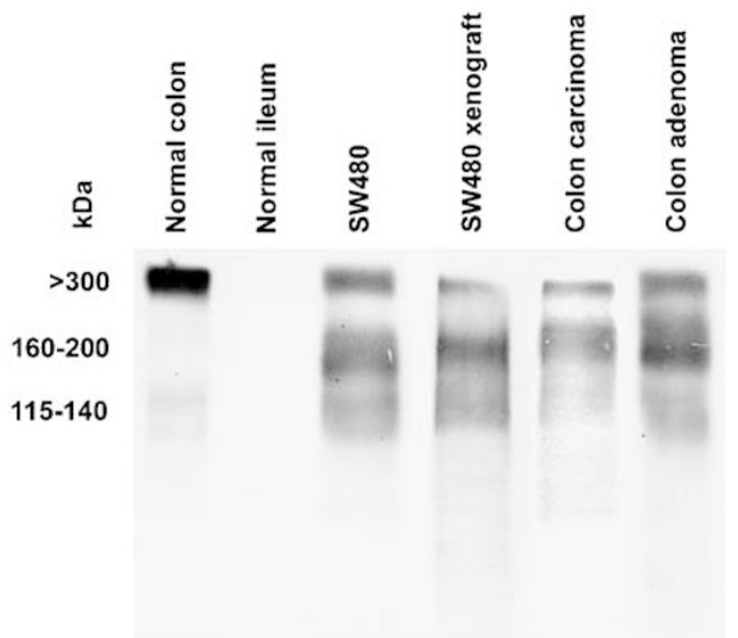

Figure 2 Immunoblotting with CO-TL1 antibody. Cell lysates in presence of $\beta$-mercaptoethanol were run on $8 \%$ SDS-polyacrylamide gels, blotted, incubated with CO-TL1 antibody and RAMPO, and visualized with the ECL method. Lane 1, normal human colorectal tissue: a main HMW band at $>300 \mathrm{kDa}$. Lane 2 , normal human ileum: negative. Lane 3, SW480 colon carcinoma cells in culture and lane 4, SW480 xenografted in -/ Balb/c mice: additionally to the $>300 \mathrm{kDa}$ band a doublet band of 160-200 and 115-140 kDa. Lane 5, colon carcinoma: a minor $>300 \mathrm{kDa}$ band and predominantly a thick broad band at $165-200 \mathrm{kDa}$. Lane 6 , colon adenoma: a thick $>300 \mathrm{kDa}$ band, a broad $165-200 \mathrm{kDa}$ band, and a diffuse band of 110-140 kDa. Note that all tumour samples contain a heterogeneous composition of more bands (with different intensity) while normal colon shows predominantly a $>300 \mathrm{kDa}$ band. expressed in essentially all three cell types, that is, goblet cells, columnar cells and endocrine cells, in both fetal, neonatal and adult colorectal epithelium. Since the colorectal antigen was completely absent in both adult and neonatal small intestine and remaining parts of the gastrointestinal tract as well as other tissues, the antibody is considered as highly specific for colorectal epithelial cells, despite sporadic reactivity with few clustered epithelial cells in for example bronchiolar epithelium (but not alveolar epithelium) and in some glands (tongue and lung). The antibody was also specific for colonocytes of rats and rabbits. In mice, however, also crypt cells of the small intestine (but not in the villi) were stained.

Although, the CO-TL1-defined antigen is found specifically in normal colonic epithelium, the expression of the antigen was apparently switched on in other parts of the digestive tract (ie stomach and small intestine), upon transformation of the epithelium to carcinoma cells, except for gutderived carcinoids. This finding indicates that COTL1 antibody not only marks colorectal carcinomas but also extends its specificity to digestive tract adenocarcinomas. Further molecular analysis will be needed to substantiate any speculation on the mechanism of the induced expression of the CO-TL1 antigen in the digestive tract upon tumour transformation. However, it is an important observation that the CO-TL1 antibody did not react with the majority of tumour samples (not digestive tract related), that is, from thyroid, lung, liver, mesothelium, bladder, kidney, prostate, testis and skin.

With respect to the gynaecologic malignancies the reactivity of the antibody varied from focal-positive traces to distinct positive reactivity in a limited number of tumours such as serous papillary ovarian adenocarcinomas, endometrioid carcinomas, borderline tumours and endocervical adenocarcinomas. The distinct but limited reactivity with ovarian carcinomas was confirmed by a similar low score in liver metastases of ovarian cancer, compared to a high positive score for colorectal carcinomas metastasized to the liver. The data suggest that the antibody CO-TL1 has diagnostic utility in differentiating between gastrointestinal tumours and especially colon tumours vs tumours of the thyroid, lung, liver, mesothelium, bladder, kidney, prostate, testis and skin. The antigen or epitope recognized by the antibody is probably proteinaceous rather than carbohydrate-like because both the paraffin sections and the Western blots remained stainable with the antibody CO-TL1 after enzymatic pretreatment with neuramidase, diastase and hyaluronidase, and deglycosylating enzymes (endo-F and - $\mathrm{H}$ ). The molecular weights were not altered by digestion with deglycosylating enzymes. Additional arguments for the protein nature of colorectal antigen were provided by the electron microscopical observations that in the mucous cells the large vesicles showed a rim of positively stained gold labelling around the negatively stained light mucous content. Moreover, 
in columnar cells, the homogeneous gold labelling was confined to the electron-dense (proteinaceous) content of the small vesicles. This labelling-specificity towards proteinaceous, but nonmucous structures supported the previous arguments that COTL1 antibody recognizes a protein (epitope) rather than a mucin substance. These data exclude the suggestions that CO-TL1 antibody might react with any of the (intestinal types of) mucins (MUC-1-7 antigens, MUC15) as characterized by several authors. ${ }^{22-25}$

The SDS-PAGE-Western blot analysis on colon tumour samples revealed a second interesting characteristic of this colorectal antigen. The antigen was found in three different molecular weight sizes, that is, a high molecular weight form (HMW; $>300 \mathrm{kDa}$ ) in normal colorectal tissues, and two lower molecular weight forms associated with colorectal tumours (LMW; 160-200 and 115-140 kDa). Striking similarity to the different expression forms of the APC-gene is inevitable since APC gene expresses, at full-length, a protein of $312 \mathrm{kDa}$ in normal intestinal tissue while mutant, truncated APC proteins in tumours have a MW of 117-147 and $200 \mathrm{kDa} \cdot{ }^{26}$ Alternative splicing of APC has also been shown to contribute to different APC isoforms. ${ }^{27-29}$ Although our colorectal antigen data looked rather similar by showing a $>300 \mathrm{kDa}$ wild type and two tumour-associated isoforms (115-140 and 160$200 \mathrm{kDa}$ ), the immunohistochemical characterization of CO-TL1 indicated considerable differences with the staining pattern of anti-APC antibodies. Full-length APC was found both in the nucleus and at lateral cell borders and basolateral cytoplasm in normal cryptic goblet cells of colon, ${ }^{30}$ but staining was not found in the mucous vacuoles. ${ }^{31}$ However, our CO-TL1 antibody stained not merely the goblet cells but also all other colonocytes. In goblet cells the label was found in large secretory granules above the nucleus, while in columnar cells, the label was found basolaterally and as apical membrane staining as well as in the Golgi areas. In the endocrine cells, however, strong labelling was also found in subnuclear basolateral areas. Thus, the CO-TL1 staining pattern differed largely from the APC-staining pattern in normal colon cells. Since our antibody reacted with both 'wild-type colorectal antigen' and tumour-associated low molecular weight types, it supports the high rate of positive immunohistochemical staining of adenomas and colon carcinomas, in contrast to a much lower rating to the APCstaining pattern in adenomas $(70 \%)$ and carcinomas $(17 \%)$ in Iwamoto's study. ${ }^{31}$ The expression pattern of the APC proteins largely differs from the CO-TL1 antigen expression pattern as APC proteins are also present in normal epithelium of the bladder, small intestine, oesophagus, stomach and epidermis, in neural tissues, and in normal renal cells and renal cell carcinomas..$^{29,32,33}$ Our CO-TL1 antibody staining was never found in/on the nucleus while truncated APC staining in the nucleus has been clearly demonstrated in other studies. ${ }^{30}$ None of the immunohistochemical reports on subcellular localization of APC in various cells and tissues in human or mouse ${ }^{13,30,34}$ showed a localization that is similar to our CO-TL staining pattern.

Although the immunohistochemical profile of CO-TL1 antibody has some similarity with the DAS-1 antibody ${ }^{5,35}$ (ie nonreactive with small intestine epithelium) the antigen recognized by DAS-1 is much smaller $(40 \mathrm{kDa})$ and the antigen was localized mainly in the basolateral membranes of colonocytes, without precise specification of the cell types involved. The CO-TL1 antibody also differs from the 5E9 antibody that detects a $O$-glycan epitope on MUC-2 in goblet cells exclusively in colonic crypts ${ }^{12}$ with a molecular weight of $550 \mathrm{kDa}$, but not in columnar cells, while CO-TL1 antibody recognized a $>300 \mathrm{kDa}$ colon-antigen commonly expressed in all three different types of colonocytes, as defined by Shamsuddin et al. ${ }^{12,36}$ The identical CO-TL1 staining pattern of a common structural or carrier-like protein present in all three types of vesicles in the three cell types in fact supports the suggestion that mucous cells and columnar cells and probably the endocrine cells as well are derived from a single precursor stem cell. ${ }^{37,38}$ The shift from an HMWcolorectal antigen (wild type) to LMW-variants of the antigen in colon tumours coincides immunohistochemically with a shift from coarse granular COTL1 staining to a fine granular staining in adenomas and confined apical membrane staining in carcinomas. This shift might be considered as a transformation from normal mucous colonocytes to tumour cells. $^{39}$

In conclusion, the MoAb CO-TL1 recognizes an antigen specifically expressed in normal colorectal epithelium with a HMW $>300 \mathrm{kDa}$ as well as in corresponding dysplastic epithelia and adenomas/ carcinomas with LMW forms of 160-200 and 115$140 \mathrm{kDa}$. The antibody stained all normal colonocytes, $100 \%$ of the colorectal adenomas and the majority of colon carcinomas (86\%). Therefore, the antibody is sensitive for detecting colorectal tumours. However, the antibody detects also other gastrointestinal adenocarcinomas and few carcinomas of the ovary, uterus, breast and pancreas. In combination with a negative keratin-7 staining (OV-TL12/30), a positive CO-TL1 staining in fact provides a practical advantage in surgical pathology as a double confirmation for colorectal or gastrointestinal origin. In diagnostic pathology, adenocarcinomatous metastases positive with the CO-TL1 antibody are never derived from malignancies of the thyroid, lung, liver, bladder, kidney, prostate, testis, serous membranes of body cavities and skin.

\section{Acknowledgements}

We are indebted to Stephanie Roberts for the hybridoma work; Coby van Run, Marja van den 
Berg, Agnes van den Berg, Leonie Katin and Andre Slappendel for their excellent immunohistochemical assays; Jan Koedam, for all animal care and handling at the Central Animal Laboratory; Huib Croes for helpful assistance; Dr Wilbert Peters, Deptartment of Gastroenterology (UMC Nijmegen, the Netherlands) and Professor Dr Theo Wobbes, Deptartment of Surgery (UMC Nijmegen, the Netherlands) for providing digestive tract samples; Dr W Dinjens, Deptartment of Pathology (Erasmus University, Rotterdam, the Netherlands) for the cell line E5583 and the xenograft sections.

\section{References}

1 Grady WM, Markowitz SD. Genetic and epigenetic alterations in colon cancer. Annu Rev Genomics Hum Genet 2002;3:101-128.

2 Hara A, Saegusa M, Mitomi H, et al. Colonic mucincarbohydrate components in colorectal tumors and their possible relationship to MUC2, p53 and DCC immunoreactivities. Pathol Res Pract 2000;196: 159-166.

3 Taylor-Papadimitriou J, Burchell JM, Plunkett T, et al. MUC1 and the immunobiology of cancer. J Mammary Gland Biol Neoplasia 2002;7:209-221.

4 Tobi M, Maliakkal BJ, Alousi MA, et al. Cellular distribution of a colonic adenoma-associated antigen as defined by monoclonal antibody Adnab-9. Scand J Gastroenterol 1992;27:737-742.

5 Onuma EK, Amenta PS, Jukkola AF, et al. A phenotypic change of small intestinal epithelium to colonocytes in small intestinal adenomas and adenocarcinomas. Am J Gastroenterol 2001;96:2480-2485.

6 Gold DV, Cardillo TM. Monoclonal antibody G47 engineered to be reactive with colorectal tumor mucin. Hybrid Hybridomics 2001;20:343-350.

7 Berezowski K, Stastny JF, Kornstein MJ. Cytokeratins 7 and 20 and carcinoembryonic antigen in ovarian and colonic carcinoma. Mod Pathol 1996;9:426-429.

8 Loy TS, Calaluce RD, Keeney GL. Cytokeratin immunostaining in differentiating primary ovarian carcinoma from metastatic colonic adenocarcinoma. Mod Pathol 1996;9:1040-1044.

9 Ramaekers F, van Niekerk CC, Poels L, et al. Use of monoclonal antibodies to keratin 7 in the differential diagnosis of adenocarcinomas. Am J Pathol 1990;136: 641-655.

10 van Niekerk CC, Ramaekers FC, Hanselaar AG, et al. Changes in expression of differentiation markers between normal ovarian cells and derived tumors. Am J Pathol 1993;142:157-177.

11 Wauters CC, Smedts F, Gerrits LG, et al. Keratins 7 and 20 as diagnostic markers of carcinomas metastatic to the ovary. Hum Pathol 1995;26:852-855.

12 van der Wurff AA, ten Kate J, Marx PT, et al. Expression of a marker for colonic crypt base cells is correlated with poor prognosis in human colorectal cancer. Gut 1998;42:63-70.

13 Reinacher-Schick A, Gumbiner BM. Apical membrane localization of the adenomatous polyposis coli tumor suppressor protein and subcellular distribution of the beta-catenin destruction complex in polarized epithelial cells. J Cell Biol 2001;152:491-502.
14 Kawachi H, Takizawa T, Eishi Y, et al. Absence of either gastric or intestinal phenotype in microscopic differentiated gastric carcinomas. J Pathol 2003;199: 436-446.

15 Xing PX, Prenzoska J, Layton GT, et al. Secondgeneration monoclonal antibodies to intestinal MUC2 peptide reactive with colon cancer. J Natl Cancer Inst 1992;84:699-703.

16 van Niekerk CC, Jap PH, Ramaekers FC, et al. Immunohistochemical demonstration of keratin 7 in routinely fixed paraffin-embedded human tissues. J Pathol 1991;165:145-152.

17 Ouwendijk J, Moolenaar CE, Peters WJ, et al. Congenital sucrase-isomaltase deficiency. Identification of a glutamine to proline substitution that leads to a transport block of sucrase-isomaltase in a pre-Golgi compartment. J Clin Invest 1996;97:633-641.

18 Batge B, Bosslet K, Sedlacek HH, et al. Monoclonal antibodies against CEA-related components discriminate between pancreatic duct type carcinomas and nonneoplastic duct lesions as well as nonduct type neoplasias. Virchows Arch A Pathol Anat Histopathol 1986;408:361-374.

19 Bosslet K, Luben G, Schwarz A, et al. Immunohistochemical localization and molecular characteristics of three monoclonal antibody-defined epitopes detectable on carcinoembryonic antigen (CEA). Int J Cancer 1985;36:75-84.

20 Poels LG, Peters D, van Megen Y, et al. Monoclonal antibody against human ovarian tumor-associated antigens. J Natl Cancer Inst 1986;76:781-791.

21 van de Molengraft FJ, van Niekerk CC, Jap PH, et al. OV-TL 12/30 (keratin 7 antibody) is a marker of glandular differentiation in lung cancer. Histopathology 1993;22:35-38.

22 Baldus SE, Hanisch FG, Putz C, et al. Immunoreactivity of Lewis blood group and mucin peptide core antigens: correlations with grade of dysplasia and malignant transformation in the colorectal adenoma-carcinoma sequence. Histol Histopathol 2002;17:191-198.

23 Jass JR. Mucin core proteins as differentiation markers in the gastrointestinal tract. Histopathology 2000;37: 561-564.

24 Pallesen LT, Berglund L, Rasmussen LK, et al. Isolation and characterization of MUC15, a novel cell membrane-associated mucin. Eur J Biochem 2002;269: 2755-2763.

25 van Klinken BJ, Einerhand AW, Duits LA, et al. Gastrointestinal expression and partial cDNA cloning of murine Muc2. Am J Physiol 1999;276:G115-G124.

26 Smith KJ, Johnson KA, Bryan TM, et al. The APC gene product in normal and tumor cells. Proc Natl Acad Sci USA 1993;90:2846-2850.

27 Bala S, Sulekova Z, Ballhausen WG. Constitutive APC exon 14 skipping in early-onset familial adenomatous polyposis reveals a dramatic quantitative distortion of APC gene-specific isoforms. Hum Mutat 1997;10: 201-206.

28 Kraus C, Reina S, Sulekova Z, et al. Immunochemical identification of novel high-molecular-weight protein isoforms of the adenomatous polyposis coli (APC) gene. Int J Cancer 1996;65:383-388.

29 Pyles RB, Santoro IM, Groden J, et al. Novel protein isoforms of the APC tumor suppressor in neural tissue. Oncogene 1998;16:77-82.

30 Anderson CB, Neufeld KL, White RL. Subcellular distribution of Wnt pathway proteins in normal and 
neoplastic colon. Proc Natl Acad Sci USA 2002;99: 8683-8688.

31 Iwamoto M, Ahnen DJ, Franklin WA, et al. Expression of beta-catenin and full-length APC protein in normal and neoplastic colonic tissues. Carcinogenesis 2000; 21:1935-1940.

32 Midgley CA, White S, Howitt R, et al. APC expression in normal human tissues. J Pathol 1997;181: 426-433.

33 Peçina S, Paveliç K, Paveliç J. Loss of heterozygosity and protein expression of APC gene in renal cell carcinomas. J Mol Med 1999;77:446-453.

34 Zhang T, Otevrel T, Gao Z, et al. Evidence that APC regulates survivin expression: a possible mechanism contributing to the stem cell origin of colon cancer. Cancer Res 2001;61:8664-8667.
35 Das KM, Sakamaki S, Vecchi M, et al. The production and characterization of monoclonal antibodies to a human colonic antigen associated with ulcerative colitis: cellular localization of the antigen by using the monoclonal antibody. J Immunol 1987;139:77-84.

36 Shamsuddin AM, Phelps PC, Trump BF. Human large intestinal epithelium: light microscopy, histochemistry, and ultrastructure. Hum Pathol 1982;13:790-803.

37 Alameda F, Curell R. Carcinoid tumors with focal mucin production. Appl Pathol 1989;7:361-366.

38 Barrett P, Hobbs RC, Coates PJ, et al. Endocrine cells of the human gastrointestinal tract have no proliferative capacity. Histochem J 1995;27:482-486.

39 Specian RD, Oliver MG. Functional biology of intestinal goblet cells. Am J Physiol 1991;260: C183-C193. 